\title{
Forest Fragmentation and Its Potential Implications in the Brazilian Amazon between 2001 and 2010
}

\author{
Izaya Numata, Mark A. Cochrane \\ Geographic Information Science Center of Excellence, South Dakota State University, Brookings, USA \\ Email: Izaya.numata@sdstate.edu
}

Received August $12^{\text {th }}$, 2012; Revised September $17^{\text {th }}$, 2012; Accepted September $30^{\text {th }}$, 2012

\begin{abstract}
In recent decades, human development pressures have results in conversions of vast tracts of Amazonian tropical rain forests to agriculture and other human land uses. In addition to the loss of large forest cover, remaining forests are also fragmented into smaller habitats. Fragmented forests suffer several biological and ecological changes due to edge effects that can exacerbate regional forest degradation. The Brazilian Amazon has had greatly contrasting land cover dynamics in the past decade with the highest historical rates of deforestation (2001-2005) followed by the lowest rates of forest loss in decades, since 2006. Currently, the basin-wide status and implications of forest fragmentation on remnant forests is not well known. We performed a regional forest fragmentation analysis for seven states of the Brazilian Amazon between 2001 and 2010 using a recent deforestation data. During this period, the number of forest fragments ( $>2$ ha) doubled, nearly 125,000 fragments were formed by human activities with more than $50 \%$ being smaller than 10 ha. Over the decade, forest edges increased by an average of 36,335 km/year. However, the rate was much greater from 2001-2005 (50,046 km/year) then 2006-2010 (25,365 km/year) when deforestation rates dropped drastically. In 2010, 55\% of basin-wide forest edges were $<10$ years old due to the creation of large number of small fragments where intensive biological and ecological degradation is ongoing. Over the past decade protected areas have been expanded dramatically over the Brazilian Amazon and, as of 2010, 51\% of remaining forests across the basin are within protected areas and only $1.5 \%$ of protected areas has been deforested. Conversely, intensive forest cover conversion has been occurred in unprotected forests. While 17\% of Amazonian forests are within $1 \mathrm{~km}$ of forest edges in 2010, the proportion increases to $34 \%$ in unprotected areas varying between $14 \%$ and $95 \%$ among the studied states. Our results indicate that the Brazilian Amazon now largely consists of two contrasting forest conditions: protected areas with vast undisturbed forests and unprotected forests that are highly fragmented and disturbed landscapes.
\end{abstract}

Keywords: Amazon; Forest Fragmentation; Forest Degradation; Conservation

\section{Introduction}

Amazonian forests have undergone extensive land cover changes over the past decades, presenting the highest rates of deforestation among the Pan Tropic region (Archard et al., 2004; Hansen et al., 2008; Baccini et al., 2012). Forest conversion into land use in this region has affected regional and global ecosystems including climate, hydrology and carbon fluxes (Defries et al., 2002; Asner et al., 2005; Coe et al., 2009; Soares et al., 2010; Numata et al., 2011). Deforestation also fragments contiguous forests into smaller and smaller pieces, inducing ecological and biological changes in forest ecosystems (Lovejoy et al, 1986; Nascimento et al., 2004; Laurance et al., 2011). As a result, vast areas of remaining but fragmented forests in Amazonia are threatened to forest degradation.

The effects of forest fragmentation vary primarily as functions of edge penetration distance, spatial arrangements and time of persistence of forest fragments (Laurance et al., 1997, 2007). Edge effects on fragmented forest ecosystems cause numerous changes across varying edge penetration distances such as the reduction of biodiversity, changes in forest structure and specie composition, the increase of fire vulnerability, alternation of hydrological and carbon cycles, elevated tree mortality and canopy desiccation (Lovejoy et al., 1986; Laurance et al., 1998; Fahlig, 2003; Cochrane, 2003; Cochrane \& Laurance, 2002, 2008; Nascimento et al., 2004; Briant et al., 2010). And these edge associated changes can expand across large areas. For example, potential carbon emissions from biomass collapse in edge forests of $100 \mathrm{~m}$ as a result of fragmentation may reach around 3\% of those from deforestation in the Amazon region (Numata et al., 2011). Canopy desiccation in tropical dry forest in eastern Amazonia, was observed up to $2.7 \mathrm{~km}$ into fragmented forests based upon satellite data (Briant et al., 2010). However, the degree of forest fragmentation and potential edge effects are also highly variable across the Amazon region (Laurance et al., 2007, 2011; Phillip et al., 2006).

Dynamics of forest edges in landscapes are linked to ongoing deforestation (Skole \& Tucker, 1993; Ferraz et al., 2006; Numata et al., 2009). Forest cover change in the Brazilian Amazon has intensified since the mid 1990s and from the late 1990s to the first half of the 2000s was remarked with the highest historical rates of deforestation due to increasing demand of livestock and agricultural products (Nepstad et al., 2006; Morton et al., 2006; Barona et al., 2010). On the other hand, deforestation has been greatly reduced since 2006 in part due to economic downturn but also by environmental law enforcements implemented by the Government of Brazil in addition to the expan- 
sion of protected areas (Nepstad et al., 2009; Barreto \& Silva, 2010; Soares et al., 2010). According to Soares et al. (2010), $54 \%$ of remaining forests in the Brazilian Amazon were under protection in 2009 and the expansion of protected area can continue in the future. Therefore, actual areas subject to deforestation or disturbance would be less than half of the existing remaining forests. Nevertheless, the rate of Amazonian deforestation continues to decline, and by $2010,7000 \mathrm{~km}^{2}$ of forest was cleared, the lowest rate since the monitoring of deforestation started (INPE, 2012). These two contracting deforestation patterns in the past decade should have resulted in different spatial and temporal dynamics of forest fragments and edge effects on remaining forests across the Amazon. Given the interactions between socio-economic and political driving forces towards land cover changes in the Amazon, the dynamics of forest fragments become very complex and variable in space and time (Arima et al., 2008; Numata et al., 2009).

Amazonian forests prone to edge effects within $1 \mathrm{~km}$ of forest edge was $150 \%$ larger than its own deforested areas in the late 1980s (Skole \& Tuker, 1993) and further intensive forest cover changes since then have introduced vast amounts of forest edges into Amazonia (Broadbent et al., 2008; Numata et al., 2011). On the other hand, the magnitude and intensity of edge effects varies according to its spatial attributes such as fragment size and shape, the amount of edge in a landscape as well as the persistence of forest edges (Fahrig, 2003).The updated knowledge on forest fragmentation is indispensable in order to estimate its regional impacts as well as the synergetic effects with other disturbances such as forest fire, climate change and management (Laurance et al., 2001; Cochrane, 2003; Cochrane \& Laurance, 2008). However, the current status of forest fragmentation in Amazonia is not well known.

We perform the basin-wide assessment of forest fragmentation by analyzing the spatial and temporal dynamics of forest fragments in seven states of the Brazilian Amazon and discuss its potential implications for Amazonian ecosystems and the effects of land cover changes and the expansion of protected areas for the 2001-2010 time period.

\section{Data and Methodology}

For the analysis of deforestation and forest fragmentation, the INPE PRODES digital product developed by the Brazilian Institute of Space Research (INPE) was used in this study. This data provides a spatially explicit map of annual deforestation in the Brazilian Amazon since 1997 (Figure 1). The details about the methodology of the PRODES data are found in www.obt.inpe.br/prodes/metodologia.pdf. We considered the year 2001 is the starting year for our temporal analysis for the 2001-2010 period and deforestation prior to 2001 was considered as old deforestation. The PRODES data used in this study has $90 \mathrm{~m}$ pixel size or 0.81 ha per pixel. This study covers seven of the nine states of the Legal Amazon: Acre, Amapá, Amazonas, Mato Grosso, Pará, Rondônia and Roraima (Figure 1). Since only small portions of Maranhão and Tocantins, the other states of the Legal Amazon, are covered in the PRODES data and several artifacts and errors exist over Maranhão, these two states were not included in our analysis. Besides, because of a lack of good satellite imagery due to frequent cloudiness in a portion of the eastern Amazon region (Pará), an area of 25,290 $\mathrm{km}^{2}$ was eliminated from the analysis. Our study region covers $4,5000,000 \mathrm{~km}^{2}$ of the Brazilian Amazon. From this data,

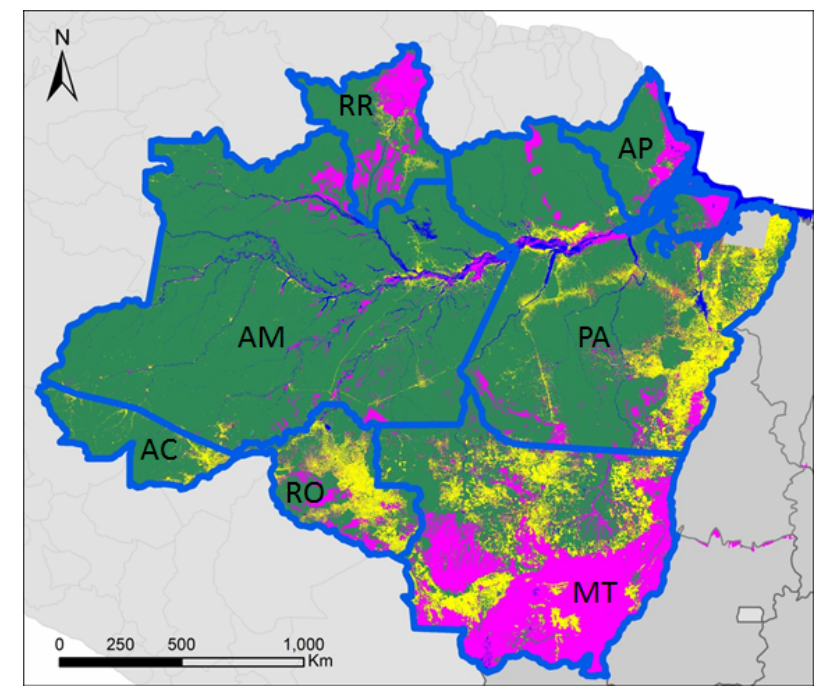

Figure 1.

The Brazilian Amazon with seven states: Acre (AC), Amapá (AP), Amazonas (AM), Mato Grosso (MT), Pará (PA), Rondônia (RO), and Roraima (RR) (2010 INPE PRODES data).

annual deforestation and the areas of remaining forests were quantified at the basinwide and statewide scales annually.

For the spatiotemporal analysis of forest fragmentation, we quantified the following variables: 1) the amount of forest fragments and its size; 2) forest edge length in $\mathrm{km}$ and density in $\mathrm{km} / \mathrm{km}^{2}, 3$ ) areas of forest prone to edge effects or edge forest considering three edge penetration distances from edges and 4) the composition of edge age and the persistence of edge. These measurements were calculated using the Interactive Data Language (IDL, Exelis VIS).

Forest fragment size influences the degree of edge effects on such as specie composition and its dynamics (Didham \& Lawton, 1999). We considered both natural and anthropogenic forest fragments for quantifying the number of forest fragments but for forest edge length, only anthropogenic forest edges are considered in the analysis. The following ranges of forest fragment sizes larger than 2 ha were considered in our analysis: $<10$ ha, 10 - 100 ha, 100 - 1000 ha, $1000-10,000$ ha and $>10,000$ ha. Forest edge length (in $\mathrm{km}$ ) and its annual changes were quantified and edge density was calculated in $\mathrm{km} / \mathrm{km}^{2}$.

Three major edge penetration distances, which each one is related to particular types of forest disturbance, are considered in this study: $100 \mathrm{~m}$ (specie composition change, forest structure and arrangement, biomass change, elevated tree mortality), $300 \mathrm{~m}$ (detectable large tree biomass loss, increase necromass/woody debris), and $1000 \mathrm{~m}$ (canopy desiccation, fire susceptibility, wind turbulence, and canopy desiccation). In order to estimate the areas of edge forests for three distances more accurately, we downscaled the PRODES data from $90 \mathrm{~m}$ pixel size into $30 \mathrm{~m}$. Then an edge distance map was created by using Euclidian distance (Figure 2). We stratified the map into the three edge distances. The changes of forest edges created and eroded and edge ages were tracked annually through the study period based upon the technique used in Numata et al. (2009). The expansion of Protected Areas between 2001 and 2010 was also included in our analysis. We used the dataset of protected areas in the Brazilian Amazon from the INPE PRODE website, www.dpi.inpe.br/prodesdigical/prodes.php, the Fundação Na 


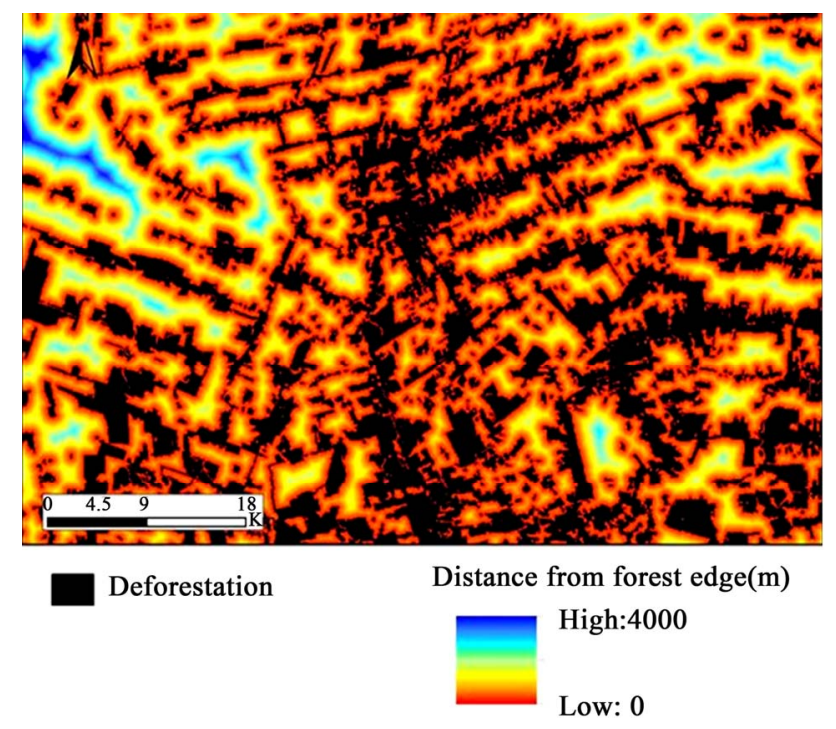

Figure 2.

Deforestation and remaining forests with a range of edge penetration distances.

cional do Índio, www.funai.gov.br., and socioambiental.org.

\section{Results and Discussion}

\section{Forest Fragments and Edge Length}

Deforestation in the 2001-2010 period has intensified forest fragmentation by doubling the number of fragments (Table 1). There are substantial amounts of natural forest fragments, i.e., those forest fragments surrounded by natural edges such as savanna and rivers, found in some states such as Amapá, Amazonas and Roraima, accounting for nearly $70 \%$ of the all forest fragments in 2001. However, all increase of forest fragments until 2010 is accounted for by anthropogenic forest fragments with the substantial increases across the studied states ranging from $85 \%$ to $130 \%$, while the numbers of natural fragments were declined. Most of these changes are found over the arc of deforestation including Rondônia, Mato Grosso and Pará (Table 1).

The increase of anthropogenic forest fragments is largely associated with the increase of small fragments (Figure 3).

The proportion of the fragments smaller than 10 ha grew by more than $20 \%$ in the study period, occupying more than $50 \%$ of the all fragments by 2010, meanwhile all the other fragments in larger sizes showed some reduction in proportion. Fragment size is vital in terms of its effects on forest ecosystems such as specie richness of many organisms and the rate of specie loss, and smaller fragments are affected more severely compared to larger ones (Lovejoy et al., 1986; Ferraz et al., 2006). Furthermore, smaller fragments are often unable to support viable populations and deleterious edge effects (Didham \& Lawton, 1999). Therefore, despite the vast areas of tropical forests remaining in the Amazon, a large amount of forest fragments may have been under the threat of specie loss and other edge effects.

Annual increments of forest edge follow the annual deforestation (Figure 4(a)). Over the study period, 2001-2010, the seven states of the Brazilian Amazon had additional 313,566 $\mathrm{km}$ of forest edge, an increase of forest edge by $36 \%$ with the
Table 1.

Changes in the amounts of forest fragments in the studied states between 2001 and 2010.

\begin{tabular}{ccccccc}
\hline & Total & Natural & Human & Total & Natural & Human \\
\hline & & $\mathbf{2 0 0 1}$ & & & $\mathbf{2 0 1 0}$ & \\
Acre & 2705 & 12 & 2693 & 6,040 & 8 & 6032 \\
Amazonas & 12,090 & 8204 & 3886 & 15,576 & 7978 & 7598 \\
Amapá & 1104 & 767 & 337 & 1613 & 718 & 895 \\
M. Grosso & 16,889 & 2815 & 14,074 & 35,777 & 2496 & 33,281 \\
Pará & 28,264 & 5494 & 22,770 & 57,053 & 4843 & 52,210 \\
Rondônia & 13,366 & 701 & 12,665 & 23,909 & 645 & 23,264 \\
Roraima & 2448 & 1597 & 851 & 3604 & 1462 & 2142 \\
\hline
\end{tabular}

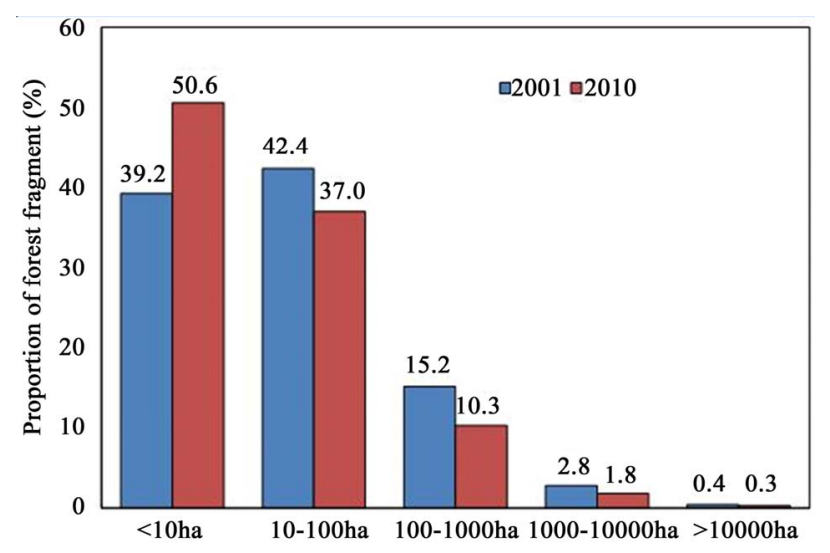

Figure 3.

Distribution of forest fragments in different sizes in 2001 and 2010.

average annual edge increase of 37,172 km. The average rate of annual edge increase in the 2001-2005 period was reduced from $48,781 \mathrm{~km} /$ year to $25,563 \mathrm{~km} /$ year in the $2006-2010$ due to the drastic decline of deforestation over this period (Figure 4(b)). All the studied states had the increase of the amount of forest edges (Figure 5(a)). Mato Grosso had the largest increase of edge, 46\%, followed by Pará, Amazonas and Rondônia, 38\%, $26 \%$ and $24 \%$, respectively. Rondônia is the most fragmented states with the edge density of $1.3 \mathrm{~km} / \mathrm{km}^{2}$, followed by Mato Grosso, Acre and Pará, while Amazonas and Amapá are the least fragmented by human (Figure 5(b)). Overall, the edge density over the Amazon Basin is $0.4 \mathrm{~km} / \mathrm{km}^{2}$. Meanwhile, many edges were destroyed due to ongoing deforestation. The total amounts of forest edges in the central Rondônia and eastern Pará were decreased while the expansion of forest fragmentation is observed in the other places in these states.

\section{Edge Forest}

Forests prone to edge effects across the Brazilian Amazon slightly expanded over the study period (Table 2). Of remaining forests in 2010, $17 \%$ is within $1000 \mathrm{~m}$ of forest edge, an increase by $3 \%$ over the 10 years, and $3 \%$ is of $100 \mathrm{~m}$ forest edge only accounting for an additional $1 \%$ to the previous estimate in 2001, which is equivalent to $536,138 \mathrm{~km}^{2}$. This amount is substantially higher compared to Skole and Tucker's 1978- 


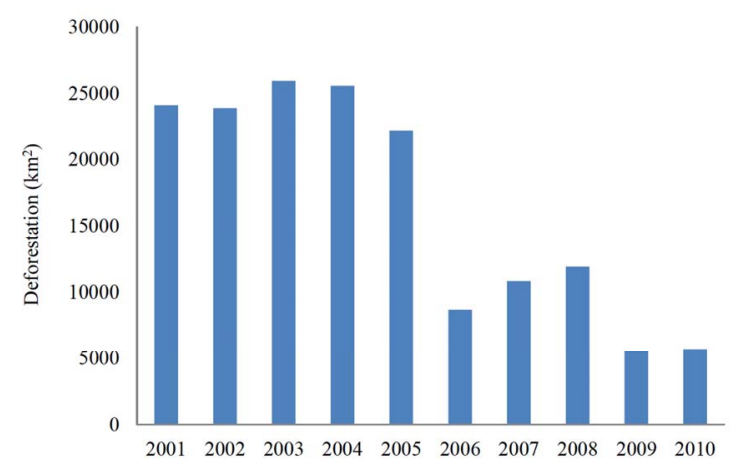

(a)

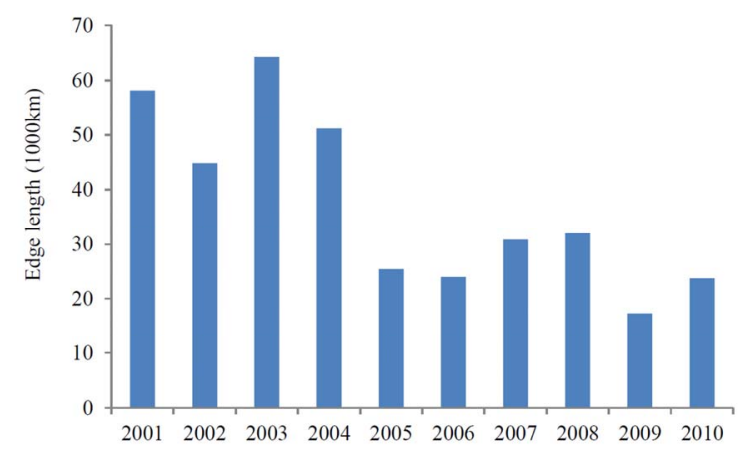

(b)

Figure 4.

(a) Annual deforestation increments and (b) annual forest edge increments for 2001-2010.
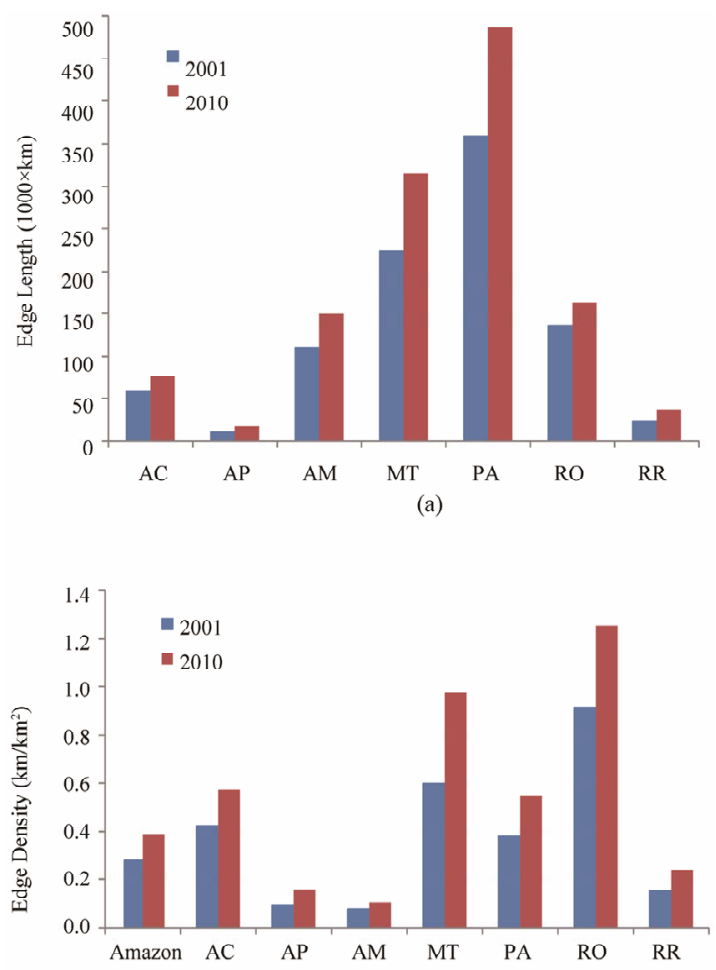

(b)

Figure 5.

(a) Changes in the total edge length and (b) edge density for seven states of the Legal Amazon between 2001 and 2010.

Table 2.

Edge forests with different penetration distances in 2001 and 2010.

\begin{tabular}{|c|c|c|c|c|c|c|c|c|}
\hline & Rem Forest $\left(\mathrm{km}^{2}\right)$ & 100 m (\%) & 300 m (\%) & 1000 m (\%) & Rem Forest $\left(\mathrm{km}^{2}\right)$ & 100 m (\%) & 300 m (\%) & $1000 \mathrm{~m}(\%)$ \\
\hline & \multicolumn{4}{|c|}{2001} & \multicolumn{4}{|c|}{2010} \\
\hline Acre & 139,942 & 3 & 10 & 25 & 135,397 & 4 & 12 & 28 \\
\hline Amazonas & $1,460,425$ & 1 & 2 & 6 & $1,452,910$ & 1 & 2 & 8 \\
\hline Amapá & 112,240 & 1 & 2 & 6 & 111,380 & 1 & 4 & 10 \\
\hline M. Grosso & 375,110 & 4 & 13 & 30 & 324,295 & 7 & 18 & 38 \\
\hline Pará & 945,202 & 3 & 8 & 17 & 889,658 & 4 & 10 & 21 \\
\hline Rondônia & 148,909 & 7 & 17 & 35 & 129,960 & 9 & 21 & 39 \\
\hline Roraima & 155,583 & 1 & 3 & 10 & 152,828 & 2 & 5 & 13 \\
\hline Total & $3,337,411$ & 2 & 6 & 14 & $3,196,428$ & 3 & 7 & 17 \\
\hline
\end{tabular}

1988 period analysis, 306,145 $\mathrm{km}^{2}$ for the equivalent study region, i.e., the seven states of the Brazilian Amazon. On the other hand, the amount of increase for $1 \mathrm{~km}$ edge distance forests in the $1978-1988$ was $201,003 \mathrm{~km}^{2}$ for the same study region, with $18,273 \mathrm{~km}^{2}$ of the average annual increase, whereas our analysis indicates that the $1 \mathrm{~km}$ buffer zone increased by $70,067 \mathrm{~km}^{2}$ in the past decade, 7,000 $\mathrm{km}^{2}$ of edge increment per year.

At the state-wide scale, Rondônia and Mato Grosso have nearly $40 \%$ of remaining forests within $1000 \mathrm{~m}$ of forest edge by 2010 , whereas less than $10 \%$ of remaining forests in Amazonas are $1000 \mathrm{~m}$ from edge. In terms of individual forest fragments, most of smaller fragments (100 ha), the edge forests vary from $10 \%$ to $70 \%$ depending on fragment shapes and the presence of natural edges such as rivers and savanna (Numata et al., 2009).

\section{Persistence of Forest Edge}

In 2010, forest edges older than 10 years dominate the Amazon Basin (44\%), whereas those created within 5 years account for a little bit larger than 20\% (Figure 6). The edge age class 6-10yr has a larger proportion compared to 1 - 5yr for all the states, which indicates the higher deforestation rates in the first five years (2001-2005) compared to the 2006-2010 period (Figures 4(a) and (b)). Overall, the amounts of newly introduced edges in the 2001-2010 period are larger compared to those created before 2001, i.e. >10 yr, except Amazonas, where 


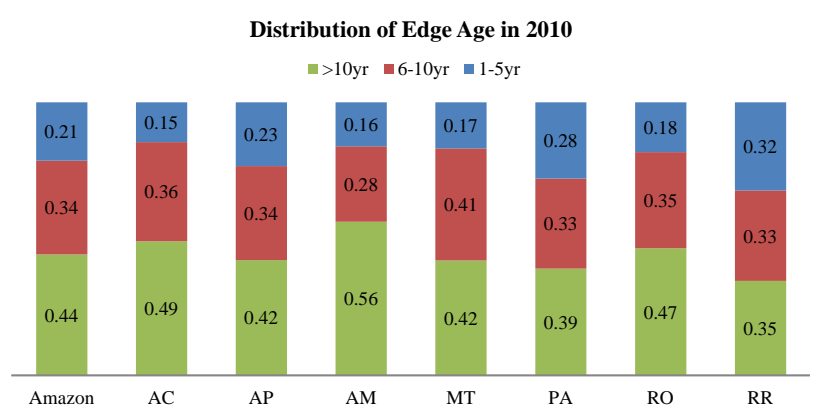

Figure 6.

Distribution of edge age in the Amazon in 2010.

the old edges occupy $56 \%$ of the total edges. Many ecological changes in forest edges occur intensively within first years after forest fragmentation such as changes in biomass and species composition (Laurance et al., 1997; D’Anglo et al., 2004). More than half of edges may be undergoing the processes of ecological and biological transitions. On the other hand, the distribution of edges with different ages varies spatially across the basin and within each state (Figure 7). Some old colonization regions such as central Rondônia along the major roads and the eastern Amazon show predominantly old edges, while extensive areas with the high amounts of young edges, $75 \%$ $100 \%$, indicate the active deforestation regions during the past decade mostly identified across the arc of deforestation but more concentrated in western Rondônia and northwestern Mato Grosso, and the regions along the new highway in Pará. This spatial pattern of forest edges with different ages indicates the shift of deforestation frontier and intensity of ecological changes associated with edge effects.

The persistence of edge varied between the first (2001-2005) and second half (2006-2010) of the study period (Figure 8). During the first five years after edge creation, the forest edges created in 2001 were reduced by $38 \%$, staying a shorter time in landscapes compared to those edges formed in 2005 which presents the reduction of edges by $25 \%$ in five years. This represents two different time periods at high and low rates of deforestation. Varying edge persistence in landscapes may have important implications for ecosystems. Numata et al. (2011) estimated that the amount of carbon emissions of biomass collapse in forest edges to all deforestation driven carbon in the Amazon was $1.7 \%-3.0 \%$ in the $2001-2005$ period, however this amount increased to $3.3 \%-5.6 \%$ in the 2006-2010, longer edge exposure period compared to the first, which demonstrates the effects of persistence of edges on regional carbon fluxes. The exposure of forest edges for longer periods may increase the risk of large scale edge effects in remaining forests as well as synergistic interactions with fires and climate change (Cochrane \& Laurance et al., 2008). On the other hand, proliferating vines and branch growth as edges age, may buffer edge intensity (Laurance et al., 2011).

\section{Protected Areas and Forest Fragmentation}

Protected areas expanded more than $100 \%$ since 2001 in the Brazilian Amazon (Table 3) and the proportion of remaining forests under protection of different categories, ie., strictly protected, sustainable use and indigenes land, grew from $23.5 \%$ in 2001 to $51 \%$ in 2010 in our study region due to their expansion per se combined with the reduction of forest areas by defore-

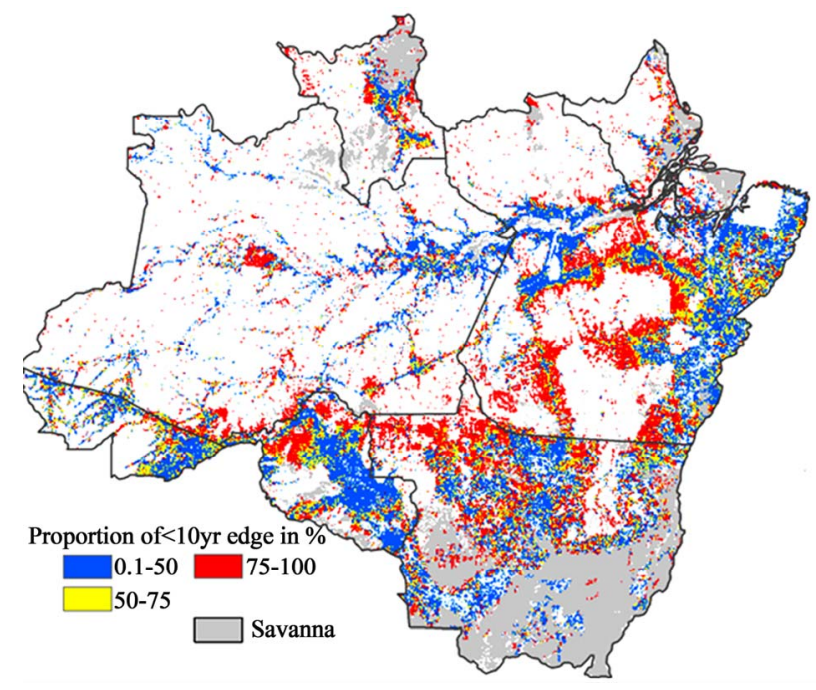

Figure 7.

Spatially explicit map of edge age of the year 2010.

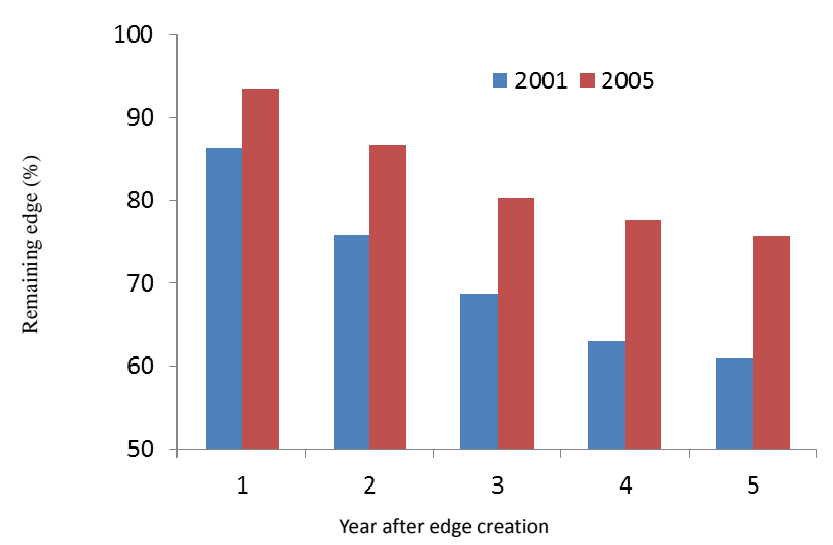

Figure 8.

Edge decay rates of forest edges created in 2001 and 2005 during five years after edge creation.

station over the past 10 years. This has certainly affected forest fragmentation of the Amazon.

Although nearly $80 \%$ of tropical forests still remain in the Brazilian Amazon (INPE 2012), less than half of this amount can be explored by human if the environmental regulations set by the Brazilian Government do not get violated. If we consider forest edge density of remaining forests outside of protected areas in the Amazon basin only, it would increase from 0.40 $\mathrm{km} / \mathrm{km}^{2}$ to $0.80 \mathrm{~km} / \mathrm{km}^{2}$ as of 2010 . In the case of Rondônia, the most fragmented state, it would have its edge density from 1.26 to $3.11 \mathrm{~km} / \mathrm{km}^{2}$. Furthermore, 34\% of remaining forests outside the protected areas in the basin would be within $1 \mathrm{~km}$ of edges, whereas 95\% of unprotected forests in Rondônia is within $1 \mathrm{~km}$ of edge. These results indicate that there are two contrasting landscapes across the Amazon. While nearly half of remaining forests will be undisturbed under protected areas, another part would be highly fragmented and disturbed landscapes. If deforestation continues only in remaining unprotected forests, the process of fragmentation occurs in smaller forest fragments, which increase edge erosion and the amount of forest edge will eventually begin to decline as remaining forests keep shrinking. 
Table 3.

Changes of remaining forests (RF) and protected areas (PA) between 2001 and 2010 for seven states of the Brazilian Amazon.

\begin{tabular}{ccccccc}
\hline & $\mathrm{RF}\left(\mathrm{km}^{2}\right)$ & $\mathrm{PA}\left(\mathrm{km}^{2}\right)$ & $\mathrm{PA} / \mathrm{RF}(\%)$ & $\mathrm{RF}\left(\mathrm{km}^{2}\right)$ & $\mathrm{PA}\left(\mathrm{km}^{2}\right)$ & $\mathrm{PA} / \mathrm{RF}(\%)$ \\
\hline Acre & $\mathbf{2 0 0 1}$ & & & $\mathbf{2 0 1 0}$ & \\
Amazonas & 139,942 & 42,590 & 30.4 & 135,397 & 78,017 & 57.6 \\
Amapá & $1,460,425$ & 261,522 & 17.9 & $1,452,910$ & 679,598 & 46.8 \\
M. Grosso & 112,240 & 19,131 & 17.0 & 111,380 & 58,593 & 52.6 \\
Pará & 375,110 & 86,301 & 23.0 & 324,295 & 114,224 & 35.2 \\
Rondônia & 945,202 & 229,541 & 24.3 & 889,658 & 537,255 & 60.4 \\
Roraima & 148,909 & 69,780 & 46.9 & 129,960 & 77,418 & 59.6 \\
Total & 155,583 & 36,828 & 23.7 & 152,828 & 85,058 & 55.7 \\
\hline
\end{tabular}

The expansion of protected areas and the law enforcement efforts led by the Government of Brazil have been an important factor of reducing deforestation over the past years (Nepstad et al., 2009; Barreto \& Silva, 2010; Soares et al., 2010). Effectiveness of the majority of Amazonian protected areas has been considered high, avoiding vast area of deforestation and minimizing carbon emissions and possible impacts of climate change on forest (Walker et al., 2009; Soares et al., 2010). Until 2010, only $1.5 \%$ of Amazonian protected areas have been deforested (INPE, 2012). Even in unprotected areas, deforestation has been reduced dramatically since 2006 and a lot of clear cutting has occurred in areas smaller than 25 ha (Escada et al., 2011). If this situation continues, regional edge effects will be reduced as forest edges remain longer in landscapes and most forest fragments will reach new equilibrium in the ecosystems (Laurance et al., 2011).

\section{Conclusion}

We performed spatial and temporal analysis of forest fragmentation in the Brazilian Amazon over the 2001-2010 period. Our results indicate that intensive forest fragmentation has occurred in the past decade, doubling the number of forest fragments predominantly with small fragments $(<100 \mathrm{ha})$, introducing new forest edges ( $<10$ years old) accounting for $55 \%$ of total forest edges as of 2010 . In unprotected forests, $34 \%$ is within $1 \mathrm{~km}$ of forest edge. Forest degradation has been accelerated with larger scale edge effects and vulnerability of fragmented forest ecosystems to synergistic interactions between fires, forest fragmentation and climate change may potentially increase. Conversely, the expansion of protected areas and the law enforcement have played very important roles in reducing deforestation and forest fragmentation over the past years. The protected areas in the Amazon grew more than $100 \%$ over the past decades and most of forest fragmentation has occurred out of the protected areas. The degree of forest fragmentation such as the increment of new forest edges varied according to the annual deforestation rates. Intensive forest fragmentation was found in 2001-2005 when the deforestation rates were high, however an opposite situation was found in the 2006-2010 period when deforestation rates dropped dramatically. As Brazil has committed to reducing deforestation rate by $80 \%$ compared to the average rate of deforestation between 1995 and 2005 until 2020 (Nepstad et al., 2009), forest fragmentation will slow down and regional edge effects on remaining forest will be reduced as forest edges remain longer and reach in new ecological equilibrium in landscapes unless Brazilian environmental policies change as it has been discussed the reform to Forest Code, that may allow landowners further forest clearing.

\section{Acknowledgements}

This work was supported by the Biological Diversity Program of the Earth Science Division of the NASA Science Mission Directorate (NNX07AF16G). We also thank Luis Maurano, Marisa Motta and Maria Isabel from INPE for their helps and comments on the digital PRODES data.

\section{REFERENCES}

Archard, F., Eva, H. D., Mayaux, P., Stibig, H. J., \& Belward, A. (2004). Improved estimates of net carbon emissions from land cover change in the tropics for the 1990s. Global Biogeochemical Cycles, 18, GB2008.

Arima, E. Y., Walker, R. T., Sales, M., Souza, C., \& Perz, S. G. (2008). The fragmentation of space in the Amazon basin: Emergent road networks. Photogrammetric Engineering \& Remote Sensing, 74, 699709.

Asner, G. P., Knapp, D. E., Broadbent, E. N., Oliveira, P. J. C., Keller, M., \& Silva, J. N. (2005). Selective logging in the Brazilian Amazon. Science, 310, 480-482. doi:10.1126/science.1118051

Baccini, A., Goetz, S. J., Walker, W. S., Laporte, N. T., Sun, M., SullaMenashe, D. et al. (2012). Estimated carbon dioxide emissions from tropical deforestation improved by carbon-density maps. Nature Climate Change, 2, 182-185. doi:10.1038/nclimate1354

Barona, E., Ramankutty, N., Hyman, G., \& Coomes, O. T. (2010). The role of pasture and soybean in deforestation of the Brazilian Amazon. Environmental Research Letters, 5, 024002. doi:10.1088/1748-9326/5/2/024002

Barreto, P., \& Silva, D. (2010). Will cattle ranching continue to drive deforestation in the Brazilian Amazon? Proceedings from the International Conference: Environment and Nautral Resources Management in Developing and Transition Economics, Clemont Ferrand, 18-19 November 2010.

Briant, G., Gond, V., \& Laurance, S. G. (2010), Habitat fragmentation and the desiccation of forest canopies: A case study from eastern Amazonia. Biological Conservation, 143, 2763-2769. doi:10.1016/j.biocon.2010.07.024

Broadbent, E. N., Asner, G. P., Keller, M., Knapp, D. E., Oliveira, P. J. C., \& Silva, J. N. (2008). Forest fragmentation and edge effects from 
deforestation and selective logging in the Brazilian Amazon. Biological Conservation, 141, 1745-1757.

doi:10.1016/j.biocon.2008.04.024

Cochrane, M. A. (2001). Synergistic interactions between habitat fragmentation and fire in evergreen tropical forests. Conservation Biology, 15, 1515-1521. doi:10.1046/j.1523-1739.2001.01091.x

Cochrane, M. A. (2003). Fire science for rainforests. Nature, 421, 913919. doi:10.1038/nature01437

Cochrane, M. A., \& Laurance, W. F. (2002). Fire as a large-scale edge effect in Amazonian forests. Journal of Tropical Ecology, 18, 311325. doi:10.1017/S0266467402002237

Cochrane, M. A., \& Laurance, W. F. (2008). Synergisms among fire, land use, and climate change in the Amazon. Ambio, 37, 522-527. doi:10.1579/0044-7447-37.7.522

Coe, M. T., Costa, M. H., \& Soares-Filho, B. S. (2009). The influence of historical and potential future deforestation on the stream flow of the Amazon river-land surface processes and atmospheric feedbacks. Journal of Hydrology, 369, 165-174. doi:10.1016/j.jhydrol.2009.02.043

D’Angelo, S. A., Andrade, A. C. S., Laurance, S. G., Laurance, W. F., \& Mesquita, R. C. G. (2004). Inferred causes of tree mortality in fragmented and intact Amazonian forests. Journal of Tropical Ecology, 20, 243-246. doi:10.1017/S0266467403001032

DeFries, R. S., Houghton, R. A., Hansen, M. C., Field, C. B., Skole, D., \& Townshend, J. (2002). Carbon emissions from tropical deforestation and regrowth based on satellite observations for the 1980s and 1990s. Proceedings of the National Academy of Sciences of the United States of America, 99, 14256-14261.

doi:10.1073/pnas.182560099

Didham, R. K., \& Lawton, J. H. (1999). Edge structure determines the magnitude of changes in microclimate and vegetation structure in tropical forest fragments. Biotropica, 31, 17-30.

Escada, M. I. S., Maurano, L. E., Rennó, C. D., Amaral, S., \& Valeriano, D. M. (2011). Avaliação de dados dos sistemas de alerta da Amazonia: DETER e SAD. In XV simpósio brasilieiro de sensoriamento remoto, Curitiba, 30 April-5 May 2011.

Fahrig, L. (2003). Effects of habitat fragmentation on biodiversity. Annual Review of Ecology Evolution and Systematics, 34, 487-515. doi:10.1146/annurev.ecolsys.34.011802.132419

Ferraz, S. F. D., Capao, L., \& Vettorazzi, C. A. (2006). Temporal scale and spatial resolution effects on Amazon forest fragmentation assessment in Rondônia. International Journal of Remote Sensing, 27, 459-472. doi:10.1080/01431160500259907

Gardner, T. A., Barlow, J., Chazdon, R., Ewers, R., Harvey, C. A., Peres, C. A., \& Sodhi., N. S. (2009). Prospects for tropical forest biodiversity in a human-modified world. Ecology Letters, 12, 561- 582. doi:10.1111/j.1461-0248.2009.01294.x

Hansen, M. C., Stehman, S. V., Potapov, P. V., Loveland, T. R., Townshend, J. R. G., DeFries, R. S. et al. (2008). Humid tropical forest clearing from 2000 to 2005 quantified by using multitemporal and multiresolution remotely sensed data. Proceedings of the National Academy of Sciences of the United States of America, 105, 94399444. doi:10.1073/pnas.0804042105

INPE (2012). PRODES-Desflorestamento nos municipios. São José dos Campos: Instituto National de Pesquisas Espaciais.

Kapos, V. (1989). Effects of isolation on the water status of forest patches in the Brazilian Amazon. Journal of Tropical Ecology, 5, 173-185. doi:10.1017/S0266467400003448

Laurance, W. F., Camargo, J. L. C., Luizao, R. C. C., Laurance, S. G., Pimm, S. L., Bruna, E. M. et al. (2011). The fate of Amazonian forest fragments: A 32-year investigation. Biological Conservation, 144, 56-67. doi:10.1016/j.biocon.2010.09.021
Laurance, W., Cochrane, M., Bergen, S., Fearnside, P. M., Delamonica, P., Barber, C., D’Angelo, S., \& Fernandes, T. (2001). The future of the Brazilian Amazon. Science, 291, 438-439. doi:10.1126/science.291.5503.438

Laurance, W., Laurance, S., \& Delamonica, P. (1998). Tropical forest fragmentation and greenhouse gas emissions. Forest Ecology and Management, 110, 173-180. doi:10.1016/S0378-1127(98)00291-6

Laurance, W. F., Laurance, S. G., Ferreira, L. V., de Merona, J. M. R. Gascon, C., \& Lovejoy, T. E. (1997). Biomass collapse in Amazonian forest fragments. Science, 278, 1117-1118.

doi:10.1126/science.278.5340.1117

Laurance, W. F., Nascimento, H. E. M., Laurance, S. G., Andrade, A. Ribeiro, J. E. S. J., Giraldo, J. P. et al. (2007). Rapid decay of tree-community composition in Amazonian forest fragments. Proceedings of the National Academy of Sciences of the United States of America, 103, 19010-19014. doi:10.1073/pnas.0609048103

Lovejoy, T. E., Bierregaard, R. O., Rylands, A. B., Malcolm, J. R., Quintela, C. E., Harper, L. H. et al. (1986). Edge and other effects of isolation on Amazon forest fragments. Conservation Biology. The science of Scarcity and Diversity, 257-285.

Morton, D. C., DeFries, R. S., Shimabukuro, Y. E., Anderson, L. O., Arai, E., Espirito-Santo, F. D., Freitas, R., \& Morisette, J. (2006). Cropland expansion changes deforestation dynamics in the southern Brazilian Amazon. Proceedings of the National Academy of Sciences of the United States of America, 103, 14637-14641. doi:10.1073/pnas.0606377103

Nascimento, H. E. M, \& Laurance, W. F. (2004). Biomass dynamics in Amazonian forest fragments. Ecological Applications, 14, S127S138. doi:10.1890/01-6003

Nepstad, D., Soares, B. S., Merry, F., Lima, A., Moutinho, P., Carter, J., et al. (2009). The end of deforestation in the Brazilian Amazon. Science, 326, 1350-1351. doi:10.1126/science.1182108

Nepstad, D. C., Stickler, C. M., \& Almeida, O. T. (2006). Globalization of the Amazon soy and beef industries: Opportunities for conservation. Conservation Biology, 20, 1595-1603. doi:10.1111/j.1523-1739.2006.00510.x

Numata, I., Cochrane, M. A., Roberts, D. A., \& Soares, J. V. (2009). Determining dynamics of spatial and temporal structures of forest edges in south western Amazonia. Forest Ecology and Management, 258, 2547-2555. doi:10.1016/j.foreco.2009.09.011

Numata, I., Cochrane, M. A., Souza, C. M., \& Sales, M. H. (2011). Carbon emissions from deforestation and forest fragmentation in the Brazilian Amazon. Environmental Research Letters, 6, 004003. doi:10.1088/1748-9326/6/4/044003

Phillips, O. L., Rose, S., Mendoza, A. M., \& Vargas, P. N. (2006). Resilience of southwestern Amazon forests to anthropogenic edge effects. Conservation Biology, 20, 1698-1710. doi:10.1111/j.1523-1739.2006.00523.x

Skole, D., \& Tucker, C. (1993). Tropical deforestation and habitat fragmentation in the Amazon-Satellite data from 1978 to 1988. Science, 260, 1905-191. doi:10.1126/science.260.5116.1905

Soares, B., Moutinho, P., Nepstad, D., Anderson, A., Rodrigues, H., Garcia, R. et al. (2010), Role of Brazilian Amazon protected areas in climate change mitigation. Proceedings of the National Academy of Sciences of the United States of America, 107, 10821-10826. doi:10.1073/pnas.0913048107

Walker, R., Moore, N. J., Arima, E., Perz, S., Simmons, C., Caldas, M., Vergara, D., \& Bohrer, C. (2009). Protecting the Amazon with protected areas. Proceedings of the National Academy of Sciences of the United States of America, 106, 10582-10586.

doi:10.1073/pnas.0806059106 